\title{
Measuring the Effect of Mergers in Greece with the Use of Financial Ratios: $A$ Bootstrapped Approach
}

\author{
Michail Pazarskis $^{1 *}$, Alexandros Alexandrakis ${ }^{1}$, Manthos Vogiatzoglou ${ }^{2}$, George Drogalas ${ }^{2}$ \\ ${ }^{1}$ Department of Accounting \& Finance, Technological Educational Institute of Central Macedonia, Serres, Greece \\ ${ }^{2}$ Department of Business Administration, University of Macedonia, Thessaloniki, Greece \\ Email: *pazarskis@gmail.com
}

How to cite this paper: Pazarskis, M., Alexandrakis, A., Vogiatzoglou, M. and Drogalas, G. (2018) Measuring the Effect of Mergers in Greece with the Use of Financial Ratios: A Bootstrapped Approach. Theoretical Economics Letters, 8, 421-431. https://doi.org/10.4236/tel.2018.83030

Received: November 20, 2017

Accepted: February 10, 2018

Published: February 13, 2018

Copyright $\odot 2018$ by authors and Scientific Research Publishing Inc. This work is licensed under the Creative Commons Attribution-NonCommercial International License (CC BY-NC 4.0). http://creativecommons.org/licenses/by-nc/4.0/

\begin{abstract}
In this study a bootstrapped data analysis from financial statement analysis is proposed to evaluate the short-run operating gains from mergers of Greek listed firms after the outbreak of the sovereign debt crisis in Greece. The examined sample consists of thirty Greek firms, in order to investigate the degree of operating gains from mergers, during a five-year-period inside the debt crisis in Greece. The results reveal that a year before and a year after the merger event, the sample firms were unable to generate short-run operating gains to several financial ratios. Also, we conclude that the use of the standard, normality based, t-test for inference between financial ratios should be done with caution.
\end{abstract}

\section{Keywords}

Mergers, Financial Ratios, Bootstrap Techniques, Greek Debt Crisis

\section{Introduction}

Mergers are mechanisms that can change dramatically, in a short time, the value of a firm [1] [2] [3]. They are frequently detected in many branches of business, since they are considered as an option for increasing profits and operating efficiency [4] [5] [6]. Diachronically, the profitability of merged firms worldwide is not always improved and this has produced an extensive subject of debate and controversy [1] [7]. Thus, mergers are often considered that either contribute to improving the operating performance or not and destroy the value of an investment undertaking merger activities or could be zero value [8] [9].

Furthermore, it is obvious that after the outbreak of the US's crisis in mid 
2007 and the Greek debt crisis in the end of 2009, the reduction of profitability dominated almost all business sections in Greece [10] [11]. In 2009, the Greek government resorted to the "support mechanism", a mechanism which was set up by the International Monetary Fund, the European Union and the European Central Bank. During the following period, the Greek companies of every size and industry were faced with a multitude of complex financial problems.

This study examines mergers of all listed firms in Greece over the period from 2009 to 2013 (after the 2009 Greek debt crisis and onwards), applying a bootstrapped data approach from financial statement analysis. For the purpose of the study, several financial ratios are extracted from financial statements of thirty merged firms (that are finally selected for the research sample), in order to measure firms' post-merger operating performance and to compare pre- and post-merger performance for one year before and after the merger announcements [5] [10] [12] [13].

The structure of the paper is as follows: the following section analyses the research design of this study (related past researches, sample and data, selection of variables-financial ratios, research methodology) and the following section presents the results. The last section concludes the paper.

\section{Research Design}

\subsection{Related Past Studies}

Several past studies on operating performance after mergers that employed accounting characteristics (financial ratios) concluded on ambiguous results [7]. Many of them supported an improvement in the business performance after the M\&As action [3] [14] [15], while other researchers claimed that there was a deterioration in the post-merger firm performance [1] [2] [16] [17], and others researchers concluded a "zero" result or ambiguous results from the M\&As action [6] [12] [18] [19].

Regarding the Greek market, several studies that evaluate performance of firms after M\&As using accounting ratios, as above, some of them supported an improvement in the corporate performance after the M\&As action [9] [20], while others claimed that there was a deterioration in the post-merger firm performance [10] [21], and some others concluded a "zero" result or ambiguous results from the M\&As action [11]. The main characteristics of studies that examined the changes with ratios in post-merger performance of acquiring firms are the different choices of measures which vary form study to study, while always exists the susceptibility of accounting information under the possible different accounting policies [17].

\subsection{Sample Data}

From a sample of all mergers, the transactions of listed firms in the period from 2009 to 2013 in Greece are tracked, which are 56 merger events. Secondly, from them for further analysis, are excluded the firms that performed merger activi- 
ties in less than a one-year period before and after the several merger examined events. Also, from this preliminary sample some firms were excluded, which have been de-listed from the Athens Exchange for various reasons (bankruptcy, not meeting the standards of the market, etc.), as well as the firms with bank activities that present several peculiarities in their accounting evaluation.

Finally, thirty acquiring firms are selected and examined that consists the final firm sample that executed one merger action as acquirers in Greece during the period from 2009 to 2013 . This final sample with thirty merged firms is satisfying as it includes all the merger events of listed firms in the Greek market at the above referred period of the Greek debt crisis (according to the sample criteria of this study) and reliable in comparison to prior accounting studies conducted in significantly larger markets such as US and UK or the Australian market, with similar sample firms, as: [2]: $n=36,[12]: n=50,[22]: n=38,[23]: n=38$.

The study proceeds to an analysis only of listed firms as their financial statements are published and it is easy to find them and evaluate from them firm's post-merger performance. Furthermore, it should be remarked that the merger activities of the listed Greek firms have been tracked from their announcements on the web site of the Athens Exchange in Greece and with the examination of the annual reports of the Athens Exchange. The accounting data of the study (accounting measures for the ratios' computation) are extracted from the financial statements of the merger-involved firms, which were received from the published data on the Athens Exchange's website.

After the beginning of the Greek debt crisis, there is a scarcity of studies how crisis affected business activities, especially after mergers. From this point of view, this study applies a bootstrapped data approach from financial statement analysis. For the purpose of the study, several financial ratios are extracted from financial statements of the merged firms, in order to measure firms' post-merger operating performance and to compare pre- and post-merger performance for one year before and after the merger announcements.

\subsection{Ratios-Quantitative Variables}

Financial ratios are widely used for modeling purposes both by practitioners and researchers, as their analysis is one of the most valuable tools for the decision-making of many interested parties, stakeholders: owners, management, personnel, competitors, academics, etc. Their analysis facilitates inter-company as well as intra-company comparisons beyond various argumentations [10] [11] [21]. The post-merger operating performance of a firm is evaluated with its performance at some accounting ratios. For the purpose of this study, after the analysis of accounting data (financial statements) twelve financial ratios are employed, which are the following ratios (see Table 1).

There are many other approaches for accounting evaluation performance, different from the above. Return on investment (ROI) type of measures are considered as the most popular and the most frequently used when accounting variables are utilized to determine performance [11]. However, in considering 
Table 1. Classification of financial ratios.

\begin{tabular}{|c|c|c|}
\hline Variable & Ratio & Ratio analysis \\
\hline \multicolumn{3}{|c|}{ Profitability ratios } \\
\hline V01 & EBITDA margin & $\begin{array}{l}\text { (earnings before interest, taxes, depreciation and } \\
\text { amortization-EBITDA/sales) }{ }^{\star} 100\end{array}$ \\
\hline V02 & EBIT margin & (earnings before interest and taxes-EBIT/sales) ${ }^{*} 100$ \\
\hline V03 & ROE & (net income/shareholders funds) ${ }^{\star} 100$ \\
\hline V04 & ROA & $(\text { net income/total assets) })^{*} 100$ \\
\hline \multicolumn{3}{|c|}{ Operational ratios } \\
\hline V05 & Net assets turnover & sales/(shareholders funds + long term debt) \\
\hline V06 & Interest cover & $\begin{array}{l}\text { (earnings before interest and } \\
\text { taxes-EBIT/interest expense) }\end{array}$ \\
\hline V07 & Collection period & $\left(\right.$ debtors/sales) ${ }^{\star} 360$ \\
\hline V08 & Credit period & $(\text { creditors } / \text { sales) })^{*} 360$ \\
\hline \multicolumn{3}{|r|}{ Structure ratios } \\
\hline V09 & Current ratio & current assets/current liabilities \\
\hline V10 & Liquidity ratio & (current assets - stocks)/current liabilities \\
\hline V11 & Solvency ratio & (shareholders funds/total assets) ${ }^{\star} 100$ \\
\hline V12 & Gearing & (non current liabilities + loans)/shareholders funds \\
\hline
\end{tabular}

Kaplan's (1983) [24] arguments against excessive use of ROI types of measurements, the above referred ratio selection of this study is confirmed as better, as:

“... any single measurement will have myopic properties that will enable managers to increase their score on this measure without necessarily contributing to the long-run profits of the firm" (Kaplan, 1983, p. 699).

Thus, an adoption of additional and combined measures is believed to be necessary in order to provide a holistic view of the short-term operating performance of a firm.

\subsection{Using Bootstrapping as Methodology}

Bootstrapping [25] is a method to derive statistical properties of the sampling distribution of estimators by relying on random sampling with replacement. The bootstrap assumes that the sample is a very good representative of the population and, therefore, the estimates from the sample are equal, or at least very close to the true population values. Instead of assuming any parametric distribution as the underlying distribution, it employs the (non-parametric) empirical distribution function to compute/estimate, usually through simulation, the true sampling distribution.

The question is why and when should one use the bootstrap procedure? There are three main reasons according to Carpenter \& Bithell (2000) [26]:

- When the asymptotic sampling distribution is very difficult to derive, as is the case of multi-stage estimators, or estimators that are non-linear functions of the estimated model parameters, like elasticities that are calculated from 
slope coefficients.

- When the actual asymptotic sampling distribution is very different from the one assumed by the theory.

- When bootstrap produces approximations that converge faster, for certain statistics, than the approximations based on asymptotic theory.

Our analysis falls mainly in the second category. It is a well documented fact [27] [28] that financial ratios are non normal, since they exhibit positive skewness and excess kurtosis, therefore the results of standard t-tests are subject to significant type I errors (incorrect rejection of the true null) that can have huge implications to the decision making process. In a later section of this study we will meet the normality assumption hypothesis and we will provide evidence that financial ratios under consideration are far from normal. In this study we employ the bootstrap t-test method of Efron \& Tibshirani (1986) [29], to test weather mergers during the Greek economic crisis improve operating performance as this is depicted in financial ratios, by avoiding the well documented pitfall of non-normality of financial ratios [28] [30] [31].

\subsection{Bootstrapped T-Test}

Assuming that the sample at hand represents the unknown underlying distribution fairly well, we can calculate approximate critical values from the percentiles of the empirical CDF of a series of bootstrap replications of the $t$-statistic. The steps of the method are the following:

1) Create two transformed data set with equal means, to satisfy the null hypothesis $\left(\mathrm{H}_{0}: \mu_{X}=\mu_{Y}\right)$.

2) Draw $B$ independent bootstrap samples $\left(x_{b}^{*}, y_{b}^{*}\right)$, of size $n$, from $(x, y)$. It is recommended that $B \geq 1000$.

3) Estimate the $t$-value for each bootstrap sample with

$$
t_{b}^{*}=\frac{\bar{Y}_{b}-\bar{X}_{b}}{s_{p} \sqrt{\frac{2}{n}}}, \quad s_{p}=\sqrt{\frac{s_{X_{b}}^{2}+s_{Y_{b}}^{2}}{2}} .
$$

4) Order the bootstrap replications of $t$, such that: $\left(t_{1}^{*} \leq t_{2}^{*} \leq t_{B}^{*}\right)$. The lower and upper critical value of the t-test are the $\left(B \cdot \frac{a}{2}\right)$-th and $B \cdot\left(1-\frac{a}{2}\right)$-th elements, respectively.

For example, if $B=1000$, the lower and upper critical values are the 25-th and the 975 -th elements of the $t_{b}^{*}$ 's.

\section{Results}

\subsection{Results of the Bootstrap T-Test}

The results of the bootstrap t-test procedure are depicted in the following Table 2.

Our results are in line with some previous studies on the field, where there is 
Table 2. Results of the bootstrap t-test to twelve financial ratios, pre and post-merger.

\begin{tabular}{cccccc}
\hline & & & \multicolumn{2}{c}{$95 \%$ Confidence interval } & \\
\cline { 4 - 5 } Variable & Name of ratio & t-value & Lower bound & $\begin{array}{c}\text { Upper } \\
\text { bound }\end{array}$ & p-value \\
\hline V01 & EBITDA margin & -1.5345 & -1.9585 & 3.232 & 0.146 \\
V02 & EBIT margin & -1.7347 & -2.6222 & 2.758 & 0.178 \\
V03 & ROE & 2.1732 & -3.668 & 2.3846 & $0.076^{*}$ \\
V04 & ROA & -0.5346 & -1.8722 & 1.9621 & 0.554 \\
V05 & Net assets turnover & 0.38525 & -1.7258 & 7.629 & 0.802 \\
V06 & Interest cover & -1.047 & -1.8346 & 3.6295 & 0.252 \\
V07 & Collection period & -1.7657 & -1.5715 & 1.8915 & $0.03^{* * *}$ \\
V08 & Credit period & -0.6774 & -1.6712 & 2.143 & 0.452 \\
V09 & Current ratio & 1.7219 & -8.554 & 14.2196 & 0.614 \\
V10 & Liquidity ratio & 1.7221 & -9.3666 & 13.5516 & 0.644 \\
V11 & Solvency ratio & -0.4747 & -2.1963 & 2.434 & 0.652 \\
V12 & Gearing & 0.2599 & -1.678 & 5.338 & 0.826 \\
\hline
\end{tabular}

Note: As the inferences of the analysis showed in our results of the bootstrap t-test to twelve financial ratios, pre- and post-merger, that the p-value corresponds to the probability of the null hypothesis: $H_{0}: \bar{X}_{\text {pre }}=\bar{X}_{\text {post }}$ the latter being accepted. Asterisk(s) denote the rejection of the null in 10\% (5\%) level.

no clear picture if merger totally improve operating performance (as performance is measured with financial ratios). Out of the twelve ratios, only two exhibit improved performance (ROE and Collection period), while two of them (EBITDA margin and EBIT margin) are showing marginally deteriorating performance. For all the other ratios there is no (statistically significant) change.

\subsection{The Normality Assumption Revisited}

In this study we employed a bootstrap t-test procedure to avoid making assumptions about the underlying distribution of the test statistic. But is this decision justified by the data? If we had resorted to the normality based t-test we would conclude that three more ratios exhibit statistically significant differences, pre and post merger, namely Current Ratio and Liquidity Ratio, were there seems to be improved performance and EBIT margin where it seems to be worsening performance. However the simulated $\mathrm{t}$-values are far from normal. In Table 3 the skewness, kurtosis and the p-value of the Jarque-Bera normality test, of the simulated bootstrap t-values, are depicted. According to it, the normality hypothesis is strongly rejected in all cases and there is significant positive skewness to the financial ratios, as predicted by the theory, see for example So (1994) [32], therefore we conclude that the use of the standard, normality based, t-test for inference between financial ratios should be done with caution.

In Table 4 the empirical distribution function of each ratio, along with the corresponding histogram of the simulated values is depicted. 
Table 3. Descriptive statistics of the sampling distribution.

\begin{tabular}{cccc}
\hline Name of ratio & Skewness & Kurtosis & JB test p-value \\
\hline EBITDA margin & 0.86 & 4.65 & 0 \\
EBIT margin & 0.12 & 3.49 & 0.002 \\
ROE & -0.72 & 4.72 & 0 \\
ROA & 0.09 & 3.65 & 0 \\
Net assets turnover & 2.03 & 7.91 & 0 \\
Interest cover & 0.94 & 4.56 & 0 \\
Collection period & 0.52 & 4.08 & 0 \\
Credit period & 0.57 & 4.66 & 0 \\
Current ratio & 1.95 & 13.05 & 0 \\
Liquidity ratio & 1.26 & 7.53 & 0 \\
Solvency ratio & 0.16 & 3.18 & 0.05 \\
Gearing & 1.97 & 9.29 & 0 \\
\hline
\end{tabular}

Note: Descriptive statistics of the bootstrapped t-test values. JB test p-value is the probability of accepting the null of the Jarque Bera test with $H_{0}$ : The distribution is normal.

\section{Conclusions}

One of the main elements of contemporary corporate restructuring is the formation of new business entities via mergers. This study proposed a bootstrapped data analysis from financial statement analysis to evaluate the short-run operating gains from mergers of Greek listed firms after the outbreak of the sovereign debt crisis in Greece

The final firm sample that is examined is thirty acquiring firms are executed at least one merger action as acquirers in Greece during the period from 2009 to 2013. For these firms, after the analysis of their accounting data (financial statements), twelve financial ratios are employed for measuring their operating performance.

Also, this study employs the bootstrap t-test method of Efron \& Tibshirani (1986) [29], to test whether mergers during the Greek economic crisis improve operating performance as this is depicted in financial ratios, by avoiding the well documented pitfall of non-normality of financial ratios.

Our results for a crisis period are in line with some previous studies on the field, where there is no clear picture if merger totally improves operating performance (as performance is measured with financial ratios). Out of the twelve ratios, only two exhibit improved performance (ROE and Collection period), while two of them (EBITDA margin and EBIT margin) are showing marginally deteriorating performance. For all the other ratios there is no (statistically significant) change. Also, we conclude that the use of the standard, normality based, $\mathrm{t}$-test for inference between financial ratios should be done with caution.

Last, future extensions of this study could examine a larger sample that could 
Table 4. The asymptotic distribution of the t-statistic, for the 12 financial ratios.
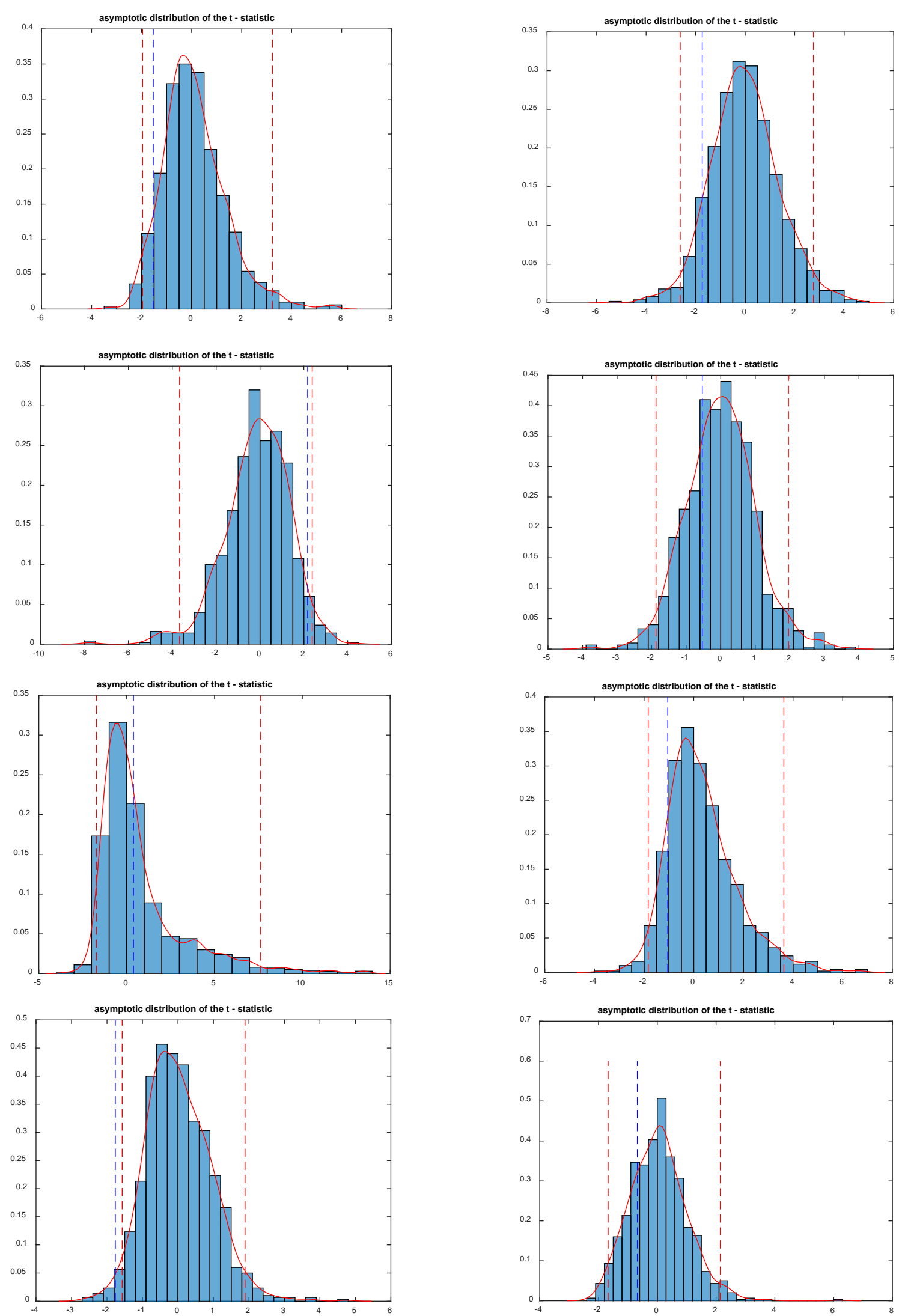

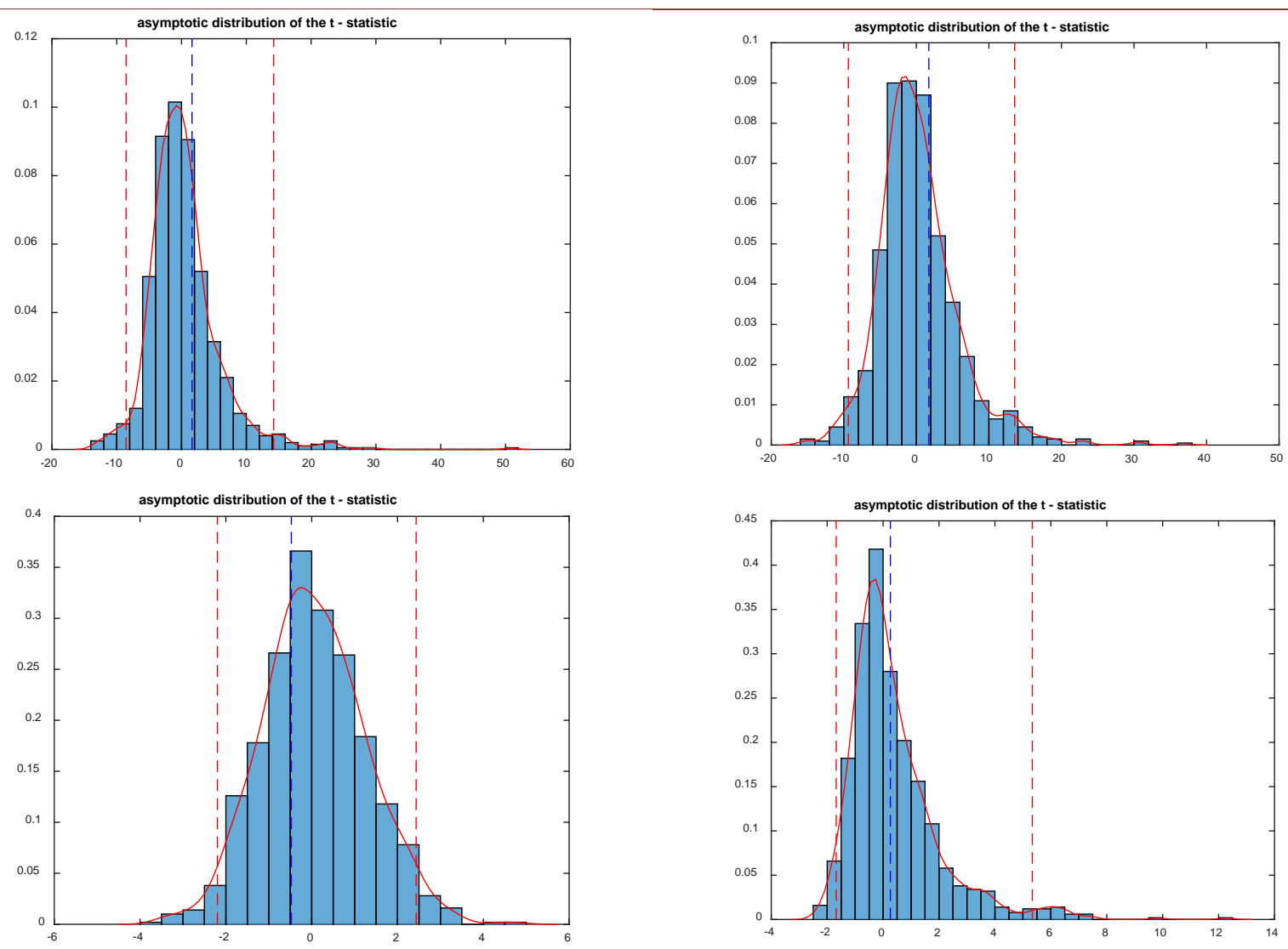

Note: Asymptotic distribution for the twelve financial ratios of the study. The dotted red lines correspond to the 0.025 and the 0.975 critical values and the dotted blue line the value of the t-test. Based on 1000 replications.

include not only M\&As-involved Greek firms listed in the Athens Exchange, but also non-listed firms and within other or larger time frame periods.

\section{References}

[1] Mueller, D. (1980) The Determinants and Effects of Merger: An International Comparison. Gunn \& Horn Publications, Cambridge.

[2] Sharma, D.S. and Ho, J. (2002) The Impact of Acquisitions on Operating Performance: Some Australian Evidence. Journal of Business Finance \& Accounting, 29, 155-200. https://doi.org/10.1111/1468-5957.00428

[3] Leepsa, N.M. and Mishra, C.S. (2013) Wealth Creation through Acquisitions. Decision, 40, 197-211. https://doi.org/10.1007/s40622-013-0023-Z

[4] Lubatkin, M. (1983) Merger and the Performance of the Acquiring Firm. Academy of Management Review, 8, 218-225.

[5] Ramaswamy, K.P. and Waegelein, J. (2003) Firm Financial Performance Following Mergers. Review of Quantitative Finance and Accounting, 20, 115-126. https://doi.org/10.1023/A:1023089924640

[6] Rodionov, I. and Mikhalchuk, V. (2016) M\&A Synergies in Domestic M\&A Deals in Russia in 2006-2014. Russian Management Journal, 14, 3-28. https://doi.org/10.21638/11701/spbu18.2016.201

[7] Ravencraft, D. and Scherer, F. (1988) Mergers and Managerial Performance. In: 
Coffee, J., Lowenstein, L. and Rose-Ackerman, S., Eds., Knights, Raiders and Targets. The Impact of the Hostile Takeover. Oxford University Press, Oxford, 194-210.

[8] Agrawal, A., Jaffe, J. and Mandelker, G. (1992) The Post-Merger Performance of Acquiring Firms: A Re-Examination of an Anomaly. Journal of Finance, 47, 1605-1621. https://doi.org/10.1111/j.1540-6261.1992.tb04674.x

[9] Mylonidis, N. and Kelnikola, I. (2005) Merging Activity in the Greek Banking System: A Financial Accounting Perspective. South Eastern Journal of Economics, 1, 121-144. http://www.asecu.gr/Seeje/issue04/mylonidis.pdf

[10] Pantelidis, P., Pazarskis, M., Deloudi, K. and Stamatouros, S. (2014) Do M\&As of Greek Listed Firms before the Economic Crisis Improved Their Current Liquidity and Profitability? MIBES Transactions, 8, 100-112. http://mtol.teithessaly.gr/vol8_2014/Pantelidis-Pazarskis-Deloudi-Stamatouros.pdf

[11] Pazarskis, M., Drogalas, G. and Koutoupis, A. (2017) Mergers, Taxation and Accounting Performance: Some Evidence from Greece. Journal of Accounting \& Taxation, 9, 119-130. https://doi.org/10.5897/JAT2017.0271

[12] Healy, P., Palepu, K. and Ruback, R. (1992) Does Corporate Performance Improve After Mergers? Journal of Financial Economics, 31, 135-175. https://doi.org/10.1016/0304-405X(92)90002-F

[13] Francis, J. and Martin, X. (2010) Acquisition Profitability and Timely Loss Recognition. Journal of Accounting \& Economics, 49, 161-178. https://doi.org/10.1016/j.jacceco.2009.09.003

[14] Cosh, A., Hughes, A. and Singh, A. (1980) The Causes and Effects of Takeovers in the U.K.: An Empirical Investigation for the Late 1960s at the Microeconomic Level. In: Mueller, D., Ed., The Determinants and Effects of Merger. An International Comparison, Gunn \& Horn Publications, Cambridge, 227-270.

[15] Omoye, A.S. and Aniefor, S.J. (2016) Mergers and Acquisitions: The Trend in Business Environment in Nigeria. Accounting \& Finance Research, 5, 10-19.

[16] Ravenscraft, D.J. and Scherer, F.M. (1989) The Profitability of Mergers. International Journal of Industrial Organization, 7, 101-116. https://doi.org/10.1016/0167-7187(89)90048-9

[17] Bhabra, H.S. and Huang, J. (2013) An Empirical Investigation of Mergers and Acquisitions by Chinese Listed Companies, 1997-2007. Journal of Multinational Financial Management, 23, 186-207. https://doi.org/10.1016/j.mulfin.2013.03.002

[18] Chatterjee, S. and Meeks, G. (1996) The Financial Effects of Takeover: Accounting Rates of Return and Accounting Regulation. Journal of Business Finance \& Accounting, 23, 851-868. https://doi.org/10.1111/j.1468-5957.1996.tb01155.x

[19] Ghosh, A. (2001) Does Operating Performance Really Improve Following Corporate Acquisitions? Journal of Corporate Finance, 7, 151-178. https://doi.org/10.1016/S0929-1199(01)00018-9

[20] Agorastos, K., Pazarskis, M. and Karagiorgos, T. (2013) Does Corporate Performance Improve after Domestic or International Mergers? Evidence from Greek Business at South-East Europe. In: Pazarskis, M., Ed., Mergers and Acquisitions in Greece: Evidence from Past Experience, Lambert Academic Publishing, Saarbrücken, 43-74

[21] Alexandrakis, A., Pazarskis, M., Pantelidis, P. and Perperidou, C. (2015) Exploration of the Impact of the Industry Sector at the Profitability of the Greek Listed Firms after M\&As. Proceedings of the 4th ICQQMEAS, Athens, 23-24 May 2015, 39-45. 
[22] Clark, K. and Ofek, E. (1994) Mergers as a Means of Restructuring Distressed Firms: An Empirical Investigation. Journal of Financial \& Quantitative Analysis, 29, 541-565.

[23] Manson, S., Stark, A. and Thomas, H. (1995) A Cash Flow Analysis of Operational Gains from Takeovers. Certified Research Report No. 35, The Chartered Association of Certified Accountants, London.

[24] Kaplan, S. (1983) Measuring Manufacturing Performance: A Challenge for Managerial Accounting Research. Accounting Review, 58, 686-705. http://www.jstor.org/stable/247063

[25] Efron, B. (1979) Bootstrap Methods: Another Look at the Jackknife. Annals of Statistics, 7, 1-26. http://www.jstor.org/stable/2958830

[26] Carpenter, J. and Bithell, J. (2000) Bootstrap Confidence Intervals: When, Which, What? A Practical Guide for Medical Statisticians. Statistics in Medicine, 19, 1141-1164.

https://doi.org/10.1002/(SICI)1097-0258(20000515)19:9<1141::AID-SIM479>3.0.C $\underline{\mathrm{O} ; 2-\mathrm{F}}$

[27] Ezzamel, M., Mar-Molinero, C. and Beech, A. (1987) On the Distributional Properties of Financial Ratios. Journal of Business Finance \& Accounting, 14, 463-481. https://doi.org/10.1111/j.1468-5957.1987.tb00107.x

[28] Barnes, P. (1987) The Analysis and Use of Financial Ratios: A Review Article. Journal of Business Finance and Accounting, 14, 449-461. https://doi.org/10.1111/j.1468-5957.1987.tb00106.x

[29] Efron, B. and Tibshirani, R. (1986) Bootstrap Methods for Standard Errors, Confidence Intervals, and Other Measures of Statistical Accuracy. Statistical Science, 1, 54-75. http://www.jstor.org/stable/2245500

[30] Deakin, E. (1976) Distributions of Financial Accounting Ratios: Some Empirical Evidence. Accounting Review, 51, 90-96. http://www.jstor.org/stable/245375

[31] Barnes, P. (1982) Methodological Implications of Non-Normally Distributed Financial Ratios. Journal of Business Finance and Accounting, 9, 51-62. https://doi.org/10.1111/j.1468-5957.1982.tb00972.x

[32] So, J.C. (1994) The Distribution of Financial Ratios: A Note. Journal of Accounting, Auditing and Finance, 9, 215-223. https://doi.org/10.1177/0148558X9400900205 